\title{
Geology of the Snap Lake kimberlite dyke, Northwest Territories, Canada, and its metasomatic interaction with granite
}

\author{
Alexandrina Fulop ${ }^{1}$, Maya Kopylova ${ }^{2}$, Pamela Ellemers ${ }^{1}$, Charlene Squibb ${ }^{3}$ \\ 1. De Beers Canada; 300-1601 Airport Rd., Calgary, Alberta, T2E 6Z8; \\ Alexandrina.Fulop@debeersgroup.com; Pamela.Ellemers@debeersgroup.com \\ 2. University of British Columbia, 2207 Main Mall, Vancouver, British Columbia, \\ V6T1Z4.mkopylov@eoasubc.ca \\ 3. De Beers Canada:300, 512049 Street, Yellowknife, Northwestern Territories \\ X1A1P8.Charlene.Squibb@debeersgroup.com
}

\section{Introduction}

Carbonate-rich intrusions in contact with felsic rocks theoretically should show metasomatism due to their contrasting compositions. In reality, though, metasomatism is rarely reported on kimberlite contacts. We present the first documented case of a metasomatically-produced mineralogical zonation in a kimberlite, the Snap Lake dyke. Our detailed petrographic, mineralogical and geochemical study is based on more than 100 logged drill core, 400 thin sections, >400 whole rock and microprobe analyses, detailed profiles through the contacts, powder and single-crystal X-ray diffractometry, and microdiamond data.

The Snap Lake kimberlite dyke dated at $523+/-6.9 \mathrm{Ma}$ is located in the south-central Slave Craton of northern Canada and intrudes granitoids and basic amphibolite-bearing metavolcanic rocks. The Snap Lake dyke is comprised of volumetrically prevalent hypabyssal xenolith-poor kimberlite (HK) and two types of kimberlite breccia enriched in granite and metavolcanic xenoliths. Fresh hypabyssal kimberlite (HK1) in the center of the thick dyke transitions to altered kimberlite (HK6) at the contact with granite through consecutive zones (HK2-6) parallel to the dyke walls (Fig. 1a). The same progression of alteration zones several centimeters wide develops around granite xenoliths (Fig. 1a). In thin dykes only the HK6 kimberlite facies is present. Kimberlite in alteration zones HK2-6 is richer in granite xenoliths (10-50 vol.\%) than fresh kimberlite HK1 (0-5\%). The progressive changes in the kimberlite mineralogy and texture towards dyke margins are not observed where the dyke intrudes metavolcanics (Fig. 1b).
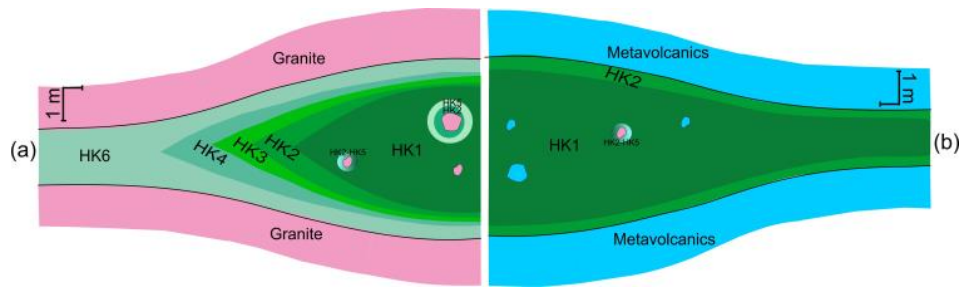

Figure 1: Zonation of alteration in the Snap Lake kimberlite dyke in contact with granite and metavolcanic rocks.

\section{Petrography and bulk rock composition of the Snap Lake kimberlite}

HK1 is comprised of olivine macrocrysts and microcrysts, and phlogopite macrocrysts set in a groundmass of monticellite, phlogopite, spinel, perovskite, and apatite crystals with interstitial lizardite and carbonate (Fig. 2a, b). Fresh olivine macrocrysts Fo 91-92\% and perovskite are identified exclusively in HK1. The groundmass carbonate in rare samples with fresh olivine is represented by calcite with up to $0.2 \mathrm{wt} \% \mathrm{SrO}$; in all other samples the groundmass carbonate is dolomite. The spinel-group mineral is titanian magnesiochromite thoughout the entire dyke. The total amount of phlogopite increases from HK1 to HK4 at the expense of serpentine, olivine, and monticellite, and then decreases from HK4 to HK6 as it is progressively replaced by multiphase phyllosilicates. The phlogopite changes its shape from elongate poikilitic with inclusions of monticellite and spinel in 
HK1, to short prismatic tabular in HK3 (Fig. 2a, b). Morphology and texture of phlogopite types correlate well with their compositions, with poikilitic phlogopite being richer in $\mathrm{Ba}$ and more severely zoned than tabular grains. The most altered HK6 is an equigranular rock made of tabular grains of a cryptocrystalline multiphase phyllosilicate composed of phlogopite + lizardite + chlorite + talc, but optically resembling phlogopite (Fig. 2c, d).

The Snap Lake kimberlite is petrographically classified as Group I. Geochemically, it is similar to Group II kimberlite reflecting the abnormally high abundance of mica for a Group I kimberlite (Fig.



Figure 2: Photos of thin sections: (a) HK1; (b) HK3; (c) multiphase phyllosilicates and (d) olivine digested by smectites in HK6.

3a). The Snap Lake kimberlite is the only known kimberlite with extremely low bulk $\mathrm{CaO}$ and $\mathrm{P}_{2} \mathrm{O}_{5}$ contents. Mineralogical and petrographic contrasts between the identified HK zones are accompanied by subtle and gradual changes in the bulk rock composition. HK1 shows the lowest $\mathrm{K}_{2} \mathrm{O}$ and $\mathrm{SiO}_{2}$, and the highest $\mathrm{Fe}_{\text {Total }}$ and $\mathrm{MgO}$. In contrast, HK2-6 are enriched in $\mathrm{K}_{2} \mathrm{O}$ and $\mathrm{SiO}_{2}$ due to the reaction with granite (Fig. 3b). The overall similarity in diamond content and size frequency distribution between HK1-2 and HK3-6 rocks is consistent with their crystallization from a single batch of magma.

Several post-emplacement processes modified the kimberlite. An early process was a reaction of olivine and monticellite with deuteric $\mathrm{H}_{2} \mathrm{O}$ and $\mathrm{CO}_{2}$, which led to serpentinization, replacement of calcite by dolomite, alteration of perovskite and decomposition of apatite. The Calcite + Olivine assemblage is not stable in the presence of hydrous $\mathrm{CO}_{2}$ and transforms to hydrous silicate + dolomite at $\mathrm{T} \sim 500^{\circ} \mathrm{C}$ and $100 \mathrm{MPa}$ (Tracy, Frost, 1991). Dolomitization of calcite is thus expected in all kimberlites where exsolved magmatic $\mathrm{CO}_{2}+\mathrm{H}_{2} \mathrm{O}$ have enough time to react with the rocks. Leaching of $\mathrm{Ca}$ under $\mathrm{CO}_{2}$-rich acidic fluid regime is also observed in alteration of perovskite and its replacement by monazite and rutile. The subsequent metasomatism was a rare process unique to the Snap Lake dyke, the interaction of kimberlite and fluids with the host granite. The unusual bulk chemistry and a protracted, predominantly subsolidus recrystallization of the Snap Lake kimberlite is 
controlled by this interaction. Since formation of phlogopite in Group 1 kimberlites on a scale comparable to that of Snap Lake has not been reported in kimberlites, the Ba-poor K-rich Snap Lake
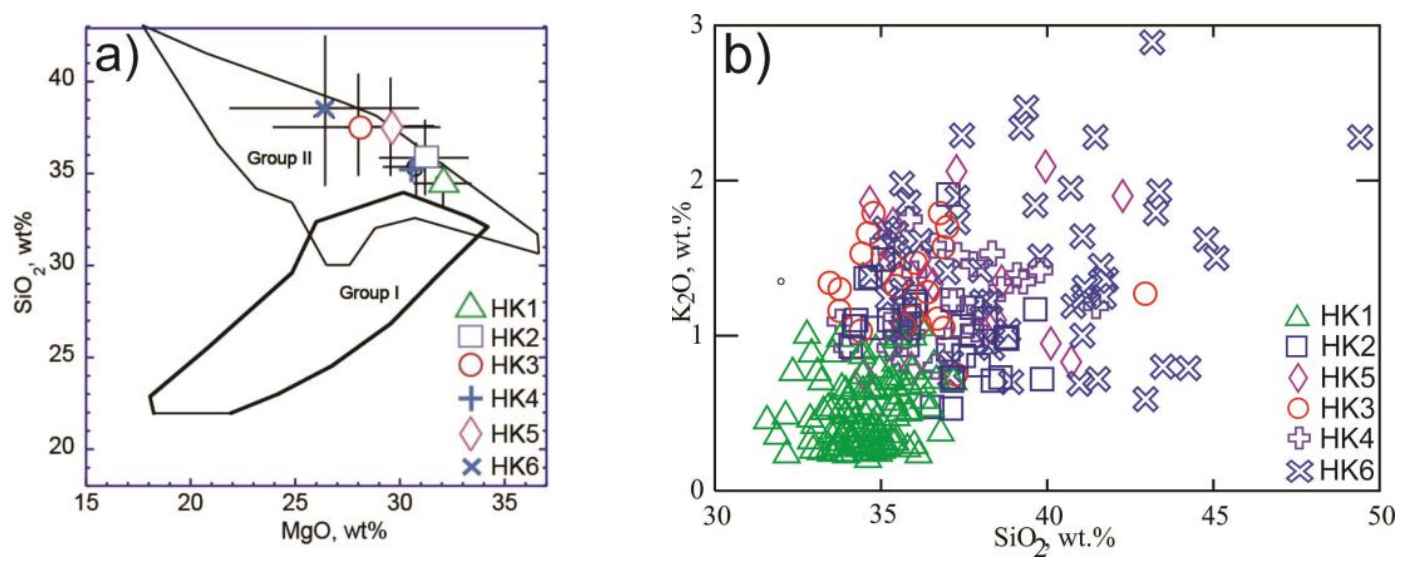

Figure 3: Bulk rock composition of Snap Lake kimberlite. a): $\mathrm{SiO}_{2}$ vs. $\mathrm{MgO}$ (wt.\%) of averaged compositions of fresh HK1 and altered kimberlites HK2-6 in comparison with global fields for Group I and Group II kimberlites. b). $\mathrm{K}_{2} \mathrm{O}$ vs. $\mathrm{SiO}_{2}$ (wt.\%) for Snap Lake fresh $\mathrm{HK} 1$ and altered kimberlites HK2-6.

phlogopite, both poikilitic and tabular, cannot be solely deuteric. In our opinion, the crystallization of abundant Ti- and K-rich phlogopite and other phyllosilicates may have been caused by the ingress of $\mathrm{K}$ and Si from the granite, which relates to xenoliths assimilation and later metasomatism.

Comparison of bulk compositions of fresh HK1 and altered HK2-6, compositions of phlogopites and geochemical profiles through the granite-kimberlite contacts suggest that $\mathrm{Mg}, \mathrm{Fe}, \mathrm{Ca}, \mathrm{Ni}$ and $\mathrm{Sr}$ moved locally from the kimberlite into the granite, while $\mathrm{K}$ and $\mathrm{Si}$ were introduced into the kimberlite. The alteration chemistry fully agrees with the theoretical T-dependent element mobilities and the composition of the contact silicate rocks. Potassic alteration in skarns is expected in contact with granites, but should be absent at contact with mafic rocks. In full correspondence with these patterns, we see the weak subsolidus secondary alteration of the kimberlite when it intrudes mafic metavolcanics, but an intense alteration at the granite-kimberlite contacts. Potassic alteration and wide skarn zones form in contact with quartzo-feldspathic rocks only at higher temperatures, above $450^{\circ} \mathrm{C}$; temperatures of a shallow kimberlite melt thus permit the high-temperature mobility of $\mathrm{K}$ and $\mathrm{Si}$.

\section{Conclusions}

Snap Lake kimberlite emplaced from a single magma batch. The altered margins of the Snap Lake dyke could be considered a rare example of contact metasomatism superimposed on the carbonaterich intrusive protolith. One can think of the Snap Lake kimberlite as of an "endofenite", i.e. a rock complementary to fenites, but replacing the igneous rock itself. The Snap Lake alteration highlights the high potential of carbonate-rich intrusions like carbonatites and kimberlites, to produce metasomatic columns when juxtaposed against felsic rocks at high temperature. Kimberlite geologists involved in resource modelling should especially be aware of susceptibility of carbonate-rich rocks to granite-induced metasomatism that deceptively look like separate emplacement phases.

\section{References}

Tracy RJ, Frost BR (1991) Phase equilibria and thermobarometry of calcareous, ultramafic and mafic rocks and iron formations. In: Kerrick, D. M. \& Ribbe, P. H. (ed) Contact metamorphism, Reviews in Mineralogy, 26, Mineralogical Society of America, pp 207 - 289 